\title{
The Training Ground (Campus) of the legio $X$ Fretensis in Jerusalem/Aelia Capitolina-A Possible Identification North of THE DAMASCUS GATE ${ }^{1}$
}

\author{
Avner Ecker \\ Bar-Ilan University, Ramat Gan
}

\begin{abstract}
This paper suggests to locate the training ground (campus) of the legio X Fretensis in the shallow valley north of the Damascus Gate, perhaps where once the siege camp of Titus was built. Topographically it is the most level ground around Jerusalem, hence fitting for a campus. Furthermore, the area was devoid of structures between $70 \mathrm{CE}$ and the 4th century, except for two monuments erected by legionary forces and dedicated to the emperors: one monument definitely dedicated to Hadrian (upon his visit) and the other either to Hadrian or less likely to Antoninus Pius. Positioning the campus in this area neatly explains why it was empty for centuries and why the cemetery of Aelia Capitolina was pushed north of the line of the "Third Wall."
\end{abstract}

Keywords: legio X Fretensis, campus, training grounds, Damascus Gate, Roman Military, Jerusalem topography, Hadrian.

One must admit that the archaeological finds from Roman Jerusalem do not allow for a clear identification of the location of the camp of the legio X Fretensis. ${ }^{2}$ One cannot even be sure if the camp had a typical "playing card" shaped plan based on the "polybian" model — such as those camps archaeologically known for more than a hundred years from the Roman West, ${ }^{3}$ or if the camp melded with the city, like the military quarter of Dura Europos. ${ }^{4}$

1 This paper was borne out of ongoing work on Aelia Capitolina together with Hannah M. Cotton-Paltiel. A preliminary discussion of the idea presented here appeared in the Hebrew proceedings of the New Studies in Archaeology of Jerusalem and its Region conference (Ecker 2018) and briefly discussed in Ecker - Cotton 2018/2019. I thank Shlomit Weksler-Bdolah for allowing me to use and reproduce some of her superb map of Aelia Capitolina.

2 Seligman 2017.

3 Stolle 1912.

4 See: Isaac 1992, 269-282; Wheeler 1996; Pollard 2000; James 2007. 
The traditional view recreated the camp as a rectangular quarter surrounded by a wall on the south western hill. ${ }^{5} \mathrm{D}$. Bar's suggestion to locate the camp in the north western corner, today's Christian quarter, assumed the same type camp. ${ }^{6}$ Other suggestions assume the "Dura Europos model": H. Geva, and later S. Weksler-Bdolah who suggested the camp was integrated into the city on its the south western hill, G. Stiebel who suggested that the camp was in the south western corner of the temple mount, and J. Seligman who suggested that the camp was spread in buildings throughout the city. ${ }^{7}$

Regardless of the location of the camp itself, it is universally agreed that whatever shape it may have taken it must have included all the compounds and buildings necessary for a roman military camp such as (e.g.) headquarters, barracks, bathhouses, and temples. ${ }^{8}$ Hence, somewhere in the vicinity of the camp there was a square or a field reserved for assemblies, parades and drills - the campus legionis.

Jerusalem's topography, its archaeological and epigraphic record all indicate that such a training ground was in the area north of the Damascus Gate. All excavations indicate that the area north of the Damascus Gate and south of the "Sukenik-Meyer" line of the "Third Wall" was for the most part empty between $70 \mathrm{CE}$ and the end of the fourth century CE (Fig. 1). Later Jerusalem expanded to the north and the area was populated with churches and monasteries. ${ }^{9}$ This settlement gap poses one of the more perplexing questions regarding the extent and borders of Aelia Capitolina. ${ }^{10}$ The line of the "Third Wall," built by Agrippa I (41-43 CE) and re-enforced during the Great Revolt, was still visible and perhaps used in the second and third centuries CE. ${ }^{11} \mathrm{Be}-$ yond this line lay the necropolis of Aelia Capitolina. J. Magness, followed by G. Avni, suggested that the line of the "Third Wall" was used to mark the northern most line of Aelia Capitolina's civic territory, hence the cemetery was north of it. The area south of the line, according to Avni, up to the Damascus Gate, was parceled out for the expansion of the Roman colony. ${ }^{12}$ It is suggested here that the Damascus Gate did in fact mark the city's pomerium and that the said area remained empty not for reasons of parcellation but rather because it was mostly occupied by the campus of the Legio X Fretensis.

5 Tsafrir 1999.

6 Bar 1998.

7 Geva 1984; Stiebel 1999; Seligman 2017; Weksler-Bdolah 2017. For a summary of most opinions, see: Magness 2011, 317-319.

8 For the buildings of Roman military camps, see: Petrikovits 1975; Hanel 2007.

9 Avni-Adawi 2015, 68; Weksler-Bdolah 2017.

10 Magness 2011, 313-316.

11 Gibson - Nagorsky 2016.

12 Magness 2000; Avni 2005; Avni 2017. 


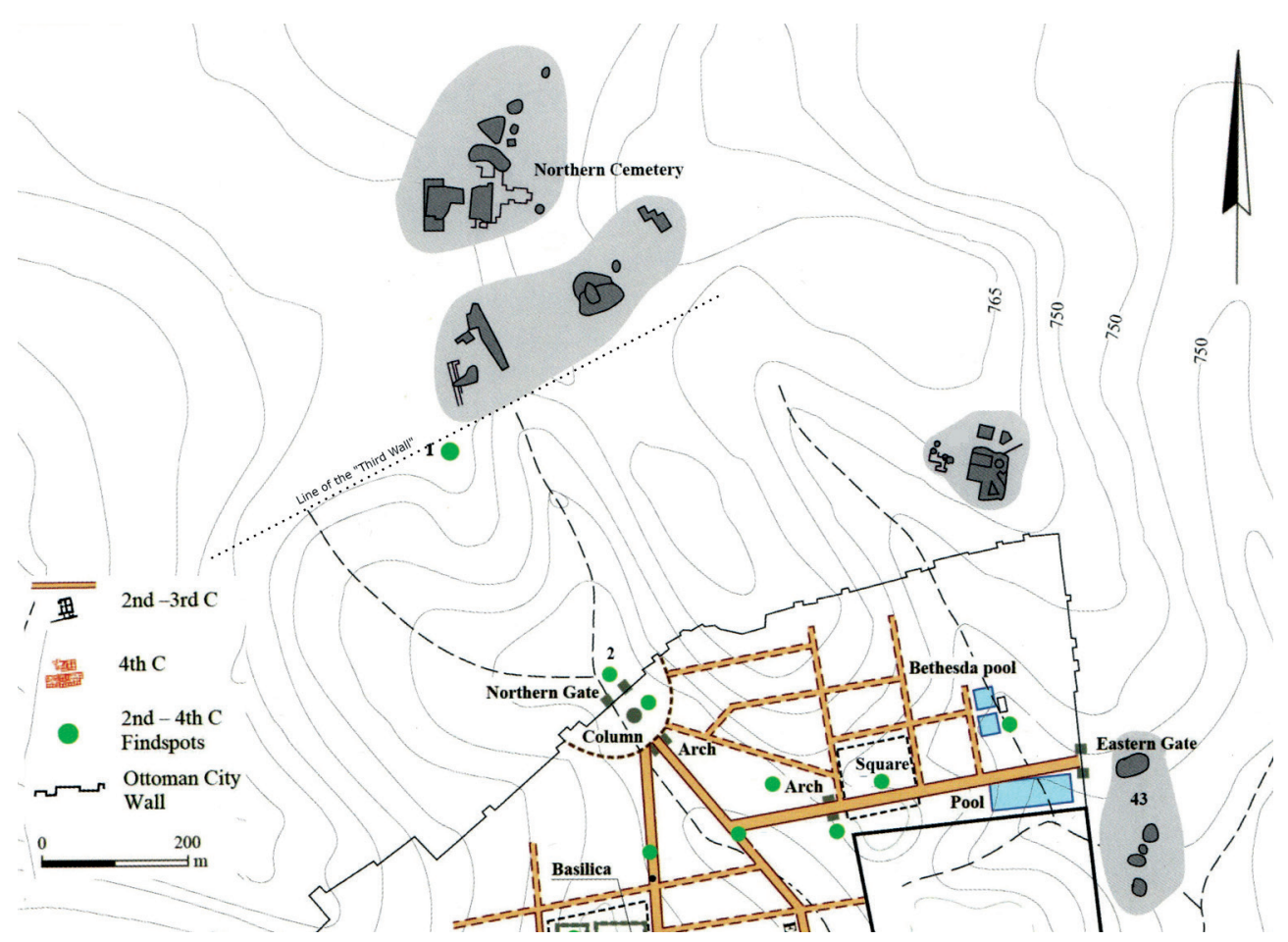

Fig. 1. Map of the northern part of Aelia Capitolina in the beginning of the fourth century: 1) Find spot of inscriptions mentioned in the text; 2) Excavations near the Damascus Gate (Hamilton 1940)

(Map based on Weksler-Bdolah 2017, with permission of the author)

\section{The Characteristics of Military Training Grounds}

A campus is a wide, level, square area near a military fort used for drills and assemblies. These squares are rarely identified in the archaeological record because they were not necessarily paved and were essentially empty. ${ }^{13}$ Some of the training grounds are recognized only by the inscriptions that stood in them. In the Roman Near-East the campus of Dura Europos is known from an inscription recording a temple and statue placed there by the cohors II Ulpia equitata probably from the time this unit joined the forces stationed in the city. ${ }^{14}$ In Palmyra the building of a new campus is recorded on an inscription from $183 \mathrm{CE} .{ }^{15}$

13 For general descriptions of training grounds, see: Davies 1968; Le Bohec 1989, 113-115; Bishop 2012. Note that some of the areas defined by Davies as training grounds were in fact temples, see especially Pudding Pie Hill in Maryport: Haynes - Wilmott 2012. A training ground could have had a temple or dedications to deities within it. One must mention the statue of an emperor or a priest that was discovered with the first inscription mentioned here (see Gibson - Nagorsky 2016). I thank Dr. G. Stiebel for drawing my attention to this. Despite the head of the stone statue, I do not think, however, that there is sufficient evidence to suggest that there was a stand alone temple north of the Damascus gate in Jerusalem, or that the entire area was a temenos.

\footnotetext{
${ }^{14}$ AE 1931, 113.

15 AE 2002, 1514.
} 
Elsewhere other training grounds have been archaeologically identified. In Vindonissa a walled gravel plaza (160 m long and $140 \mathrm{~m}$ wide) was discovered south west of the legionary camp. For about a century it was identified as a "forum." Recent excavations on the site, however, revealed that it was devoid of colonnades, temples, shops or any other monument or building that could identify it as such. The excavators now suggest identifying this walled court as a campus and point out another such campus near the camp in Carnuntum. Other such campi were discovered in Burnum and Caerleon. ${ }^{16}$ The latter was probably built over the remains of an older camp that was dismantled. ${ }^{17}$

It is well known that the best-preserved campus in the empire is the one in Lambaesis. It is located two kilometers away from the main camp of the legio II Augusta. It is a square court $(200 \times 200 \mathrm{~m})$ surrounded by a low wall. In the center of the court, on a stone paved area stood the tribunal, which also functioned as a pedestal for a commemorative column. Hadrian visited the soldiers of the legio II Augusta in $128 \mathrm{CE}$ and spoke to them in this very training ground. On one of the sides of the tribunal there was a dedication to Hadrian, and his speech (adlocutio) was inscribed on the corner pilasters. ${ }^{18}$ Based on all the above, in order to locate a campus in Jerusalem one must discover a level area large enough and this area may have had some monuments dedicated by military units.

\section{Jerusalem's Topography}

The area north of the Damascus gate is the most level ground around Jerusalem. It is generally agreed that this is where Titus placed his main siege camp, in the "Camp of the Assyrians." 19 Lately E. Dąbrowa suggested to specifically locate the "Camp of the Assyrians" in the shallow valley west of today's Nablus road, where two legionary inscriptions were discovered (see below). ${ }^{20}$ It is possible that like in Caerleon the dismantled siege camp of Titus, north of the Damascus Gate in Jerusalem, prepared the way to the transformation of the area into a training ground. Since this is a level ground that remained unsettled in the second and third centuries and in it were at least two monuments dedicated by military units, this could have been the legionary training ground.

\section{Epigraphic Evidence from Jerusalem}

Two monumental inscriptions discovered in this area represent two separate monuments that stood there during the second and third centuries CE. One inscription was discovered about 300 meters north of the Damascus gate and is a dedication of an arch or a column to Hadrian by the tenth legion, on the year of his visit - $130 \mathrm{CE}$. One half of

16 Gugl - Trumm 2015.

17 Boon 1972, 31-32, 44-45.

18 Gassend - Janon 1977/1979; Speidel 2006.

19 Josephus,. BJ 5.303, 504.

20 Dąbrowa 2015. 
the inscription was discovered in the beginning of the twentieth century and the other half in IAA excavations by R. Avner and R. Greenwald in 2014 on Nablus Road (no. 1 on Fig. 1). ${ }^{21}$ It is a $2.35 \mathrm{~m}$ long, $1 \mathrm{~m}$ high, $30 \mathrm{~cm}$ thick hard lime stone block, with an inscription set within a tabula ansata. It weighs in total approximately 1.5 tons. The text runs as follows: ${ }^{22}$

Imp(eratori) Cae[sari di]v[i Traiani] | Parthic(i) [f(ilio) divi Nerv]ae nep(oti) | Traiano [Hadri]ano Augst(o) | pont(ifici) ma[xi]m(o) trib(unicia) pot(estate) XIIII $\mid$ c [o(n)]s(uli) III P(atri) P(atriae) | L[eg(io) X F]reten[sis (2nd hand) Antoninia]nae (sic!).

To the Imperator Caesar Traianus Hadrianus Augustus, son of the deified Traianus Parthicus, grandson of the deified Nerva, high priest, invested with tribunician power for the 14th time, consul for the third time, father of the country (dedicated by) the $10^{\text {th }}$ legion Fretensis ( 2 nd hand) Antoniniana.

The second inscription is very similar in size $(0.74 \mathrm{~m}$ wide, $1 \mathrm{~m}$ high, $22-29 \mathrm{~cm}$ thick, weighing ca. 430-500 kg) and possibly of a slightly later date. It is a dedication of a monument to an emperor, probably Hadrian, possibly Antoninus Pius, by an imperial freedman who was probably in command of a force comprising vexillationes from at least five legions. The names of three of the legions are preserved: legio X Fretensis, legio II (Traiana ?), legio XII Fulminata. ${ }^{23}$ The text is very fragmentary and here is a hypothetical reconstruction and translation suggested by Werner Eck in the CIIP: ${ }^{24}$

[? Imp(eratori) Caes(ari) divi Traiani Parth(ici) f(ilio) div]i Ner[v(ae) n(epoti)|? Traiano Hadriano Aug(usto) pontifici maxi]mo | [? trib(unicia) pot(estate) XIX/XX imp(eratori) II co(n)s(uli) III p(atri) p(atriae) |--]os lib(ertus) eius $\mid$ [? per vexill(ationes) leg(ionum) -- et] X Fr(etensis) et II | [Trai(anae?) et -- et -- et] XII Fulm(inatae( | [--]

For Imperator Caesar Traianus Hadrianus Augustus, son of the deified Traianus Parthicus, grandson of the deified Nerva [-- name --]us, his freedman (had erected/built this) with the help of the vexillations of the legions ... and X Fretensis and II (Traiana?) and ... and ... and XII Fulminata.

Unlike columns and other stone architectural fragments that were sought after as spolia by late-antique builders and justified their removal from their original locations over distances (and were discovered in the area of these inscriptions), the above-mentioned inscriptions could only be used as building blocks embedded in floors and walls. The size and weight of the stones bearing these inscriptions, and the fact that two halves of one of these inscriptions were discovered close to one another, indicate that they were discovered near their original positions.

Several scholars tried to connect both inscriptions either with a monumental arch north of the Damascus gate, or even to a gate in the "Third Wall." ${ }^{25}$ S. Gibson and A. Nagorsky successfully disproved the exitance of a monumental arch north of the Damascus Gate, and it has been removed from every subsequent map of Aelia Capitolina. ${ }^{26}$

21 CIIP I.2 715; Avner et al. 2014; Ecker - Cotton 2018/2019.

22 The weight is based on the average specific gravity of hard limestones as appearing in: http://www. edumine.com/xtoolkit/tables/sgtables.htm. I thank Dr. N. Shtober-Zissu for this reference.

23 For the command of such a force in the hands of an imperial freedman from the equestrian order see: Eck 2009, 227-228.

24 CIIP I.2, 717.

25 See summary in Gibson - Nagorsky 2016, 163*-165*.

26 Gibson - Nagorsky 2016, 157*_163*. 
All previous suggestions assume that the inscriptions originated from the same monument. This assumption is unlikely because the dedicators differ between the inscriptions. It is far more probable that they originate from two separate buildings or monuments: free standing arches, gates, large statue bases of an equestrian statue of the emperor, or a commemorative column.

It is impossible to know to which monument these inscriptions belonged. But it is very reasonable to postulate that these monuments were erected within some sort of space that connected them: a forum, a large piazza in front of or within the city gate, or even a temenos. Furthermore, the space these monuments shared belonged to the legion who erected them, not a colony or any other civic body.

Monuments of such size could be found in one of two military loci: inside a large army camp or in the training ground, the campus. There is no archaeological indication that the area north of the Damascus gate served as the camp of the tenth legion, this area did not even yield stamped legionary tiles, hundreds of which were discovered within the current day area of the Old City of Jerusalem. The latter, a campus, then, is the more suitable explanation for the context of these inscriptions and the monuments which they adorned.

On the base of the commemorative column from the Lambaesis campus the dedication to Hadrian was inscribed on a stone panel very similar to the panels from Jerusalem (3.05 m long, $1.75 \mathrm{~cm}$ high, $30 \mathrm{~cm}$ thick) and with similarly sized letters (lines 1-5: $15 \mathrm{~cm}$; line $6: 9 \mathrm{~cm}):^{27}$

Imp(eratori) Cae[s]ari Traiano | Hadriano Augusto | for[ti]ss[im]o | libera[lissimo]que, | [[[le] g[io III Augusta]]] | adproba[tis campo et exe]rcitu.

To Imperator Caesar Trajan Hadrian Augustus, most gallant and most generous, the Third Augustan Legion, training field and army having been approved..$^{28}$

The inscription from Lambaesis indicates the emperor met the soldiers in their campus. Despite the paucity of examples, it is usually assumed that assembly in the training ground was common practice upon imperial and other visits. ${ }^{29}$ The legion erected a monument to Hadrian in Jerusalem in the same year as his visit, and it probably stood where the emperor was greeted ${ }^{30}-$ in the campus.

\section{Discussion and Conclusion}

The monument erected for Hadrian's visit stood on the spot at least until the beginning of third century CE when the Severan imperial epithet Antoniniana was added to it as a graffito. ${ }^{31}$ It is tempting to suggest, though not provable, that it was during the visit of

27 Speidel 2006, 7, section A; $A E$ 2006, 1008a.

28 Translation based on Speidel 2006, 7. For a photo of the inscription see: http://db.edcs.eu/epigr/bilder. php?bild=\$ZPE_175_243.jpg; an alternative reading by W. Eck and Ch. Veen, line 6: adprob[ato exe]rcitu (Eck - Veen 2010, 243).

29 Campbell 1984, 76-78; Le Bohec 1989, 115.

30 Ecker - Cotton 2018/2019.

31 Ecker 2017, 122. 
Caracalla $\mathrm{a}^{32}$ that the epithet was hastily added to this and other legionary monuments. By this time, if indeed Caracalla had met the legion there, then the campus was in use while Aelia Capitolina had already been an established colonia.

It is too early to draw lines on the map and define the training ground, though several indicators do exist. S. Gibson and A. Nagorsky identified a gate built into the line of the "Third Wall" in the second or third centuries and even suggested that one of the inscriptions mentioned here were placed over this gate. ${ }^{33}$ The line of the "Third Wall" is probably the northernmost line to which the campus could reach. Beyond this line lay the cemetery of Aelia Capitolina. The topography conveniently allows a training ground to spread ca. $200 \mathrm{~m}$ in each direction southeast of that point. ${ }^{34}$

Approximately 200 meters east of the find spot of the inscriptions ran a north-west to south east ancient road, over which Salah-e-Din street is paved today. The campus probably did not extend east of this ancient road. ${ }^{35}$

As a part of the military territory the campus lay outside the pomerium of Aelia Capitolina. It may have dictated the city's northern border marked by the Damascus Gate and drove the location of the main necropolis to the hills north of the line of the so called "Third Wall."

BIBLIOGRAPHY

Avner, R. et al. (2014), Special Announcement: A New-Old Monumental Inscription from Jerusalem Honoring Hadrian, New Studies in the Archaeology of Jerusalem and Its Region 8: 96-104 (Hebrew).

Avni, G. (2005), The Urban Limits of Roman and Byzantine Jerusalem: A View from the Necropolis, Journal of Roman Archaeology 18: 373-396.

Avni, G. (2017), The Necropolis of Aelia Capitolina: Burial Practices, Ethnicity, and the City Limits, in: G. Avni, G. D. Stiebel (eds.), Roman Jerusalem: A New Old City (JRA Supplementary Series 105), Portsmouth, RI: 122-130.

Avni, G., Adawi, Z. (2015), Excavations on Șalah ed-Din Street, Jerusalem, and the Northern Cemetery of Aelia Capitolina, 'Atiqot 80: 45-71.

Bar, D. (1998), Aelia Capitolina and the Location of the Camp of the Tenth Legion, Palestine Exploration Quarterly 130: 8-19.

Bishop, M. C. (2012), Handbook to Roman Legionary Fortresses, Barnsley-South Yorkshire.

Boon, C. G. (1972), The Roman Legionary Fortress at Caerleon, Mon, Cardiff.

Campbell, J. B. (1984), The Emperor and the Roman Army, 31 BC-AD 235, Oxford.

32 For imperial visits to Palaestina, see Eck 2014, esp. 21-22 for Caracalla.

33 Gibson - Nagorsky 2016, 163*-165*.

34 O. Gutfeld drew my attention to a slight widening in the road leading towards the Damascus Gate represented on the sixth century Madaba map and suggested that it may represent an open plaza outside the gate, possibly over the place of the campus. For the possible representation of the "Third Wall" on the Madaba map, see Magness 2000, 336.

35 Sklar-Parnes 2006. 
Dąbrowa, E. (2015), The Camp of the Assyrians and the Third Wall of Jerusalem, Scripta Iudaica Cracoviensia 13: 19-30.

Davies, R. W. (1968), The Training Grounds of the Roman Cavalry, Archaeological Journal 125: 73 100 (= Davies 1989, 93-119).

Davies, R. W. (1989), Service in the Roman Army, New York.

Eck, W. (2009), Revision lateinischer Inschriften aus Jerusalem, ZPE 169: 213-229.

Eck, W. (2014), 'Praesentia Caesaris' in der Provinz Judäa-Syria Palästina, Scripta Classica Israelica 33: 17-31.

Eck, W., Veen, Ch. (2010), Epigraphische Bronzefragmente aus Nijmegen, ZPE 175: 241-246.

Ecker, A. (2017), Who Gave the Title Antoniniana to the Legio X Fretensis?, in: G. Avni, G. D. Stiebel (eds.), Roman Jerusalem: A New Old City (JRA Supplementary Series 105), Portsmouth, RI: $117-122$.

Ecker, A., Cotton, H. M. (2018/2019), The Legio X Fretensis Welcomes the Emperor: A Latin Inscription on a Monument Erected for Hadrian in 129/130 CE, Israel Museum Studies in Archaeology 9: $58-67$.

Gassend, J. M., Janon, M. (1977/1979), La colonne d'Hadrien à Lambèse, Bulletin d'archéologie algérienne 7: 239-258.

Geva, H. (1984), The Camp of the Tenth Legion in Jerusalem: An Archaeological Reconsideration, Israel Exploration Journal 34: 239-254.

Gibson, S., Nagorsky, A. (2016), On the So-Called Head of Hadrian and a Hypothetical Roman Triumphal Arch on the North Side of Jerusalem, in: J. Patrich, O. Peleg-Barkat, E. Ben-Yosef (eds.), Arise, Walk Through the Land - Studies in the Archaeology and History of the Land of Israel in Memory of Yizhar Hirschfeld on the Tenth Anniversary of His Demise, Jerusalem: 157*-165*.

Gugl, Ch., Trumm, J. (2015), The Secret of Squares - Interpreting Large-Scale Square Structures at Roman Legionary Forts, in: L. Vagalinski, N. Sharankov (eds.), Limes XXII: Proceedings of the 22nd International Congress of Roman Frontier Studies, Ruse, Bulgaria, September 2012, Sofia: $103-110$.

Hanel, N. (2007), Military Camps, Canabae, and Vici: The Archaeological Evidence, in: P. Erdkamp (ed.), Companion to the Roman Army, Oxford: 395-416.

Haynes, I., Wilmott, T. (2012), The Maryport Altars: An Archaeological Myth Dispelled, Studia Universitatis Babeş-Bolyai, Historia 57: 25-37.

Hamilton, R. W. (1940), Excavations along the North Wall of Jerusalem, 1937-8, Quarterly of the Department of Antiquities of Palestine 10: 1-54.

Isaac, B. (1992), The Limits of Empire: The Roman Imperial Army in the East, Oxford.

James, S. (2007), New Light on the Roman Military Base at Dura-Europos: Interim Report on a Pilot Season of Fieldwork in 2005, in: A. S. Lewin, P. Pellegrini (eds.), The Late Roman Army in the Near East from Diocletian to the Arab Conquest: Proceedings of a Colloquium Held at Potenza, Aceren$z a$ and Matera, Italy (British Archaeological Reports International Series 1717), Oxford: 29-47.

Le Bohec, Y. (1989), The Imperial Roman Army, London.

Magness, J. (2000), The North Wall of Aelia Capitolina, in: L. E. Stager, J. A. Greene, M. D. Coogan (eds.), The Archaeology of Jordan and Beyond: Essays in Honor of James A. Sauer, Winona Lake: 328-339.

Magness, J. (2011), Aelia Capitolina: A Review of Some Current Debates about Hadrianic Jerusalem, in: K. Galor, G. Avni (eds.), Unearthing Jerusalem: 150 Years of Archaeological Research in the Holy City, Winona Lake, IN: 313-324.

Petrikovits, H. (1975), Die Innenbauten römischer Legionslager während der Prinzipatszeit, Wiesbaden.

Pollard, N. (2000), Soldiers, Cities, and Civilians in Roman Syria, Ann Arbor.

Seligman, J. (2017), 'Absence of Evidence' or 'Evidence of Absence'? Where Was Civilian Aelia Capitolina, and Was Jerusalem the Site of the Legionary Camp?, in: G. Avni, G. D. Stiebel (eds.), Roman Jerusalem: A New Old City (JRA Supplementary Series 105), Portsmouth, RI: 107-116. 
Sklar-Parnes, D. A. (2006), Jerusalem, Salah a-Din Street, Hadashot Arkheologiyot 118, http://www. hadashotesi.org.il/Report_Detail_Eng.aspx?id=436\&mag_id=111 (access: 16.07.2019).

Speidel, M. P. (2006), Emperor Hadrian's Speeches to the African Army: A New Text, Mainz.

Stiebel, G. D. (1999), The Whereabouts of the Xth Legion and the Boundaries of Aelia Capitolina, in: A. Faust, E. Baruch (eds.), Ingeborg Rennert Center for Jerusalem Studies: New Studies on Jerusalem, Proceedings of the Fifth Conference, December 23rd 1999, Ramat Gan: 68-103 (Hebrew).

Stolle, F. (1912), Das Lager und Heer der Römer, Strassburg.

Tsafrir, Y. (1999), The Topography and Archaeology of Aelia Capitolina, in: Y. Tsafrir, S. Safrai (eds.), The History of Jerusalem, The Roman and Byzantine Periods (70-638 C.E.), Jerusalem: 115-166 (Hebrew).

Weksler-Bdolah, S. (2014), The Foundation of Aelia Capitolina in Light of New Excavations along the Eastern Cardo, Israel Exploration Journal 64: 38-62.

Weksler-Bdolah, S. (2017), A Plan of Aelia Capitolina in the 4th c. A.D., in: G. Avni, G. D. Stiebel (eds.), Roman Jerusalem: A New Old City (JRA Supplementary Series 105), Portsmouth, RI: 7-10.

Wheeler, E. (1996), The Laxity of Syrian Legions, in: D. L. Kennedy, The Roman Army in the East (JRA Supplementary Series 18), Portsmouth, RI: 229-276. 
